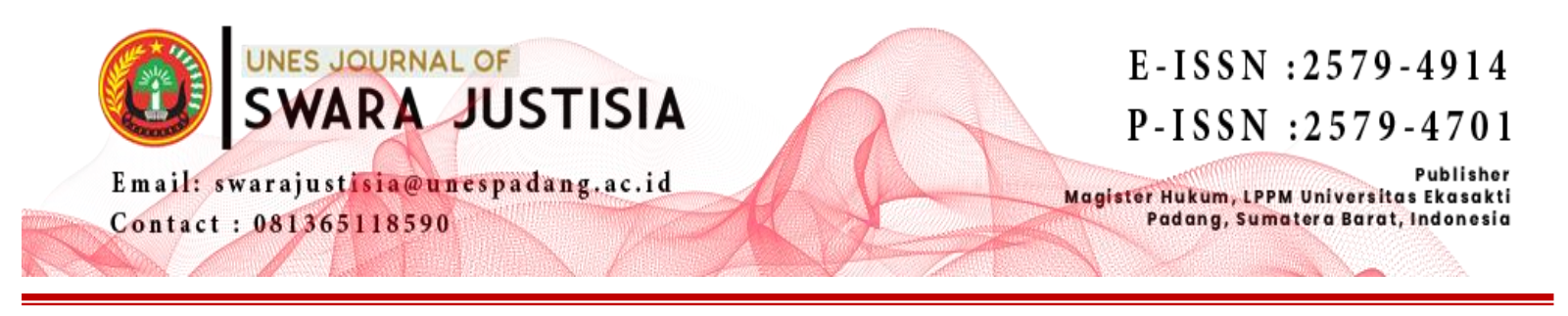

\title{
UPAYA KEPOLISIAN DALAM MEWUJUDKAN SISTEM PERADILAN PIDANA TERPADU PADA PROSES PENYIDIKAN TINDAK PIDANA NARKOTIKA (Studi Pada Ditresnarkoba Polda Sumbar)
}

\author{
Muhammad Hendri Zulfi \\ Program Magister Ilmu Hukum, Universitas Ekasakti, Padang, Indonesia \\ Email: hendrizulfi286@gmail.com
}

\begin{abstract}
The integration of the judicial sub-system in the stage of investigating narcotics crime carried out by the Directorate of Narcotics of the West Sumatra Regional Police in the implementation of various obstacles was still encountered. The West Sumatra Police Directorate of Drugs Efforts in Realizing an Integrated Criminal Justice System During the Narcotics Crime Investigation Stage is to coordinate with BNN on rehabilitation recommendations. After the investigation is deemed completed, the investigator submits the case file to the public prosecutor and takes the pre-prosecution stage. Relationship with the District Court with its decision to give permission for forced efforts by investigators. The success of the integrated criminal justice system is highly dependent on the cooperation and coordination of all components involved in the system. Fragmentary symptoms still appear to be in the operational motion of the criminal justice sub-system, especially at the investigation stage. Another obstacle is that the investigation institution is not yet independent. The coordination system that will be carried out with the public prosecutors is also not done well. Unification of the understanding of the results of the investigation is a matter that determines the results of the investigation.
\end{abstract}

Keywords: Investigations, Integrated criminal justice system, Narcotics Crime

\begin{abstract}
ABSTRAK
Keterpaduan sub sistem peradilan dalam tahap penyidikan tindak pidana narkotika dilakukan oleh Ditresnarkoba Polda Sumatera Barat dalam pelaksanaan masih ditemui berbagai kendala. Upaya Ditresnarkoba Polda Sumbar Dalam Mewujudkan Sistem Peradilan Pidana Terpadu Pada Tahap Penyidikan Tindak Pidana Narkotika adalah dengan mengadakan koordinasi dengan BNN dalam hal rekomendasi rehabilitasi. Setelah penyidikan dianggap selesai Penyidik menyerahkan berkas perkara kepada penuntut umum dan dilakukan tahap pra penuntutan. Hubungan dengan Pengadilan Negeri dengan keputusannya memberikan izin terhadap upaya paksa yang dilakukan penyidik. Keberhasilan sistem peradilan pidana terpadu sangat tergantung pada kerjasama dan koordinasi semua komponen yang terlibat di dalam sistem tersebut. Masih tampaknya gejala fragmentaris pada gerak operasional sub sistem peradilan pidana terutama pada tahap penyidikan. Kendala lain adalah Lembaga penyidikan belum mandiri. Sistem koordinasi yang akan dilakukan dengan penuntut umum pun kurang dilakukan dengan baik. Penyatuan pemahaman terhadap hasil penyidikan merupakan suatu hal yang menentukan hasil penyidikan.
\end{abstract}


Kata Kunci: Penyidikan, Sistem peradilan pidana terpadu, Tindak Pidana Narkotika

\section{PENDAHULUAN}

Proses penegakan hukum, selain adanya seperangkat peraturan perundang-undangan, dibutuhkan juga instrumen penggeraknya. Instrumen penggerak itu yaitu institusi penegak hukum dan implementasinya melalui mekanisme kerja dalam sebuah sistem, yaitu Sistem Peradilan Pidana (Criminal Justice System). Dalam perspektif sistem peradilan pidana (SPP), kekuasaan kehakiman (kekuasaan penegakan hukum) dibidang hukum pidana mencakup seluruh kekuasaan/kewenangan dalam menegakkan hukum pidana, yaitu kekuasaan penyidikan oleh badan/lembaga penyidik, kekuasaan penuntutan oleh badan/lembaga penuntut umum, kekuasaan mengadili oleh lembaga peradilan, dan kekuasaan pelaksana putusan/pidana oleh badan/lembaga permasyarakatan.

Indonesia yang menganut sistem penegakan hukum terpadu (Integrated Criminal Justice System) yang merupakan legal spirit dari KUHAP. Keterpaduan tersebut secara filosofis adalah suatu instrumen untuk mewujudkan tujuan nasional dari bangsa Indonesia. Sistem penegakan hukum terpadu berdasarkan KUHAP yang di miliki selama ini menganut asas division of function atau sistem kompartemen, yang memisahkan secara tegas tugas dan kewenangan penyidikan, penuntutan dan permeriksaan di sidang pengadilan serta pelaksanaan putusan dan penetapan pengadilan yang terintegrasi, menuju kepada sistem peradilan pidana terpadu.

Polri sebagai bagian dari Sistem Peradilan Pidana Indonesia mempunyai peran yang sangat penting dalam penegakan hukum pidana. Pasal 14 ayat (1) huruf g Undang undang Kepolisian menyatakan bahwa Polisi berwenang melakukan penyidikan tindak pidana yang sebelumnya didahului oleh tindakan penyelidikan oleh penyelidik. ${ }^{1}$ Kewenangan dimaksud meliputi pula penyelidikan dan penyidikan tindak pidana.

Tantangan lain yang dihadapi oleh penyidik Polri bukan saja berasal dari keberhasilan meneruskan suatu perkara ke pengadilan melalui kejaksaan, tetapi juga kemungkinan akan dituntut oleh pihak tersangka dan keluarganya melalui gugatan praperadilan karena kesalahan penyidik Polri itu sendiri. Hal tersebut berdasarkan pemikiran bahwa dalam pratek hukum / praktek peneakan hukum ternyata bahwa pejabat penyidik pada saat mulai mengayunkan langkah pertamanya dalam melakukan penyidikan maka secara otomatis dan secara langsung sudah terikat dengan ketentuan-ketentuan pembuktian yang dtur dalam KUHAP. Bahkan yang menjadi target penting dalam kegiatan penyidikan dalah upaya mengumpulkan alat-alat pembuktian untuk membuat terang tentang tindak pidana yang terjadi.

Penyalahgunaan dan peredaran gelap narkotika di Sumatera Barat dalam dua tahun terakhir menunjukan peningkatan yang sangat tajam, perkembangan tingkat tindak pidana penyalahgunaan narkoptika sudah sangat memprihatinkan. Kalau dulu, peredaran dan pecandu narkotika hanya berkisar di wilayah perkotaan, kini tidak ada satupun kecamatan, atau bahkan desa di Indonesia yang bebas dari penyalahgunaan dan peredaran gelap obat terlarang tersebut. Selain ibukota, daerah yang dahulunya tidak terjamah, kini menjadi sasaran pengedar narkoba adalah Provinsi Sumatera Barat.

${ }^{1}$ Puri Rahardi, Hukum Kepolisian (Profesionalisme dan Reformasi Polri), Laksbang Mediatama, Surabaya, 2007, cet. 1, hlm 27. 
Guna terciptanya kerjasama dalam mencegah dan pemberantasan penyalahgunaan dan peredaran gelap narkotika khususnya pada tahap penyidikan Ditresnarkoba Polda Sumatera Barat melakukan kerjasama dengan berbagai sub sistem yang ada dalam sistem peradilan pidana.

Berdasarkan latar belakang pemikiran yang telah dipaparkan di atas, maka rumusan permasalahan adalah upaya serta kendala dari Ditresnarkoba Polda Sumbar dalam mewujudkan sistem peradilan pidana terpadu pada tahap penyidikan tindak pidana narkotika.

\section{METODE PENELITIAN}

Spesifikasi penelitian adalah deskriptif analitis, dengan metode pendekatan yuridis normative didukung yuridis empiris. Jenis data yang digunakan adalah data sekunder. Data sekunder diperoleh dari studi dokumen dan studi kepustakaan. Data yang diperoleh kemudian dianalisa secara kualitatif .

\section{HASIL DAN PEMBAHASAN}

\section{A. Upaya Ditresnarkoba Polda Sumbar Dalam Mewujudkan Sistem Peradilan Pidana Terpadu Pada Tahap Penyidikan Tindak Pidana Narkotika}

Modus operandi kejahatan yang kompleksitas membutuhkan aparat penegak hukum yang tangguh, mempunyai motivasi kerja yang tinggi, pengalaman profesional yang tinggi guna penyidikan dan penuntutan terhadap tindak-tindak pidana tersebut. Membutuhkan kerja sama dengan lembaga-lembaga tertentu, mengikutsertakan tenagatenaga ahli di bidangnya (ahli akuntansi, ahli komputer, dan sebagainya). ${ }^{2}$

Langkah-langkah menuju keterpaduan sebenarnya memang sudah ada baik secara substansial maupun struktural, karena dalam pengertian sistem sebenarnya harus terkandung adanya suatu keterpaduan antara sub-subsistem pendukungnya. Namun dalam praktiknya ternyata masih tampak adanya gejala fragmentaris yang menunjukkan kurang adanya keterpaduan (suatu integrated).

Komponen sistem peradilan pidana di Indonesia terdiri atas unsur-unsur kepolisian, kejaksaan, pengadilan dan lembaga pemasyarakatan sebagai aparat penegak hukum. Selain itu ada satu komponen lagi yaitu komponen penasihat hukum yang meskipun bukan aparat penegak hukum tetapi mereka bersama-sama dengan polisi, jaksa, hakim, petugas pemasyarakatan sebagi penegak hukum.

Adapun lembaga yang mempunyai hubungan dengan penyidik Polri dalam penyidikan tindak pidana narkotika adalah BNN dalam hal pemberian rekomendasi rehabilitasi bagi pengguna narkotika.

Pada perkara yang apabila tersangkanya adalah anak anak juga dilakukan keterpaduan sistem dengan lembaga Bapas pada Kanwil Hukum dan HAM di Kota Padang. Koordinasi dilakukan dalam rangka pemeriksaan prilaku anak dan pendampingan bagi anak selama menjalani proses penyidikan dan rehabilitasi.

Selanjutnya adalah hubungan antara penyidik dan kejaksaan. Setelah penyidikan dianggap selesai Penyidik menyerahkan berkas perkara kepada penuntut umum. Apabila Penuntut Umum berpendapat hasil penyidikan belum lengkap, ia segera mengembalikan

\footnotetext{
${ }^{2}$ Barda Nawawi Arief, Bunga Rampai Hukum Pidana, Penerbit Alumni, Bandung, 1992, hlm. 97-100.
} 
kepada penyidik disertai petunjuknya dan penyidik wajib melengkapinya dengan melakukan pemeriksaan tambahan. Keterpaduan sistem lainnya juga terlihat dalam hal ketika dimulainya penyidikan. Penyidik ketika sudah memulai melakukan penyidikan/pemeriksaan, memberitahukan hal itu kepada penuntut umum/kejaksaan.

Saat penyidik menghentikan penyidikan, harus memberitahukan hal itu kepada Penuntut Umum sesuai dengan ketentuan pada Pasal 109 ayat (2) KUHAP, sebaliknya juga dalam hal Penuntut Umum menghentikan penuntutan, ia memberikan Surat Ketetapan kepada Penyidik berdasarkan Pasal 144 ayat (3) KUHAP. Penuntut Umum memberikan turunan surat pelimpahan perkara, surat dakwaan kepada penyidik. Demikian pula dalam hal Penuntut Umum mengubah surat dakwaan ia memberikan turrunan perubahan surat dakwaan itu kepada penyidik .

Keterpaduan juga dilakukan oleh penyidik dengan lembaga peradilan yaitu Pengadilan Negeri setempat. Hubungan antara Ketua Pengadilan Negeri dengan keputusannya memberikan perpanjangan penahanan atas permintaan penyidik. Disamping itu juga dalam upaya paksa penggeledahan dan penyitaan. Ketua Pengadilan Negeri menolak atau memberikan surat izin penggeledahan rumah atau penyitaan dan/atau surat khusus pemeriksaan surat. Setelah penggeledahan dan penyitaan dilakukan Penyidik wajib segera melapor kepada Ketua Pengadilan Negeri atas pelaksanaan penggeledahan rumah atau penyitaan yang dilakukan dalam keadaan yang sangat perlu dan mendesak sebagaimana dimaksud Pasal 34 ayat (2) dan Pasal 38 ayat (2) KUHAP. Ketika putusan sudah dijatuhkan oleh Hakim maka panitera pengadilan akan memberikan kepada panitera bukti bahwa surat amar putusan telah disampaikan kepada terpidana. Apabila terdakwa tidak menerima putusan dan menempuh upaya hukum biasa maka Panitera memberitahukan kepada penyidik tentang adanya perlawanan dari terdakwa tersebut.

Adapun upaya-upaya yang harus dilakukan agar terwujud adanya sistem peradilan pidana yang terpadu, mandiri dan berwibawa dengan berlandaskan cepat, sederhana dan biaya ringan oleh penyidik pada Satnarkoba Polda Sumbar, antara lain pada awalnya dengan membuat suatu perencanaan penyidikan. Perencanaan (planning), di dalamnya terkandung berbagai program yang akan dilaksanakan. Perencanaan didefinisikan sebagai tindakan yang dilakukan untuk menentukan tujuan organisasi. Perencanaan berarti mengidentifikasi berbagai tujuan untuk kinerja organisasi di masa mendatang serta memutuskan tugas danpenggunaan sumber daya yang diperlukan untuk mencapainya.

Sebelum dilakukannya penyidikan dibuatlah suatu rencana penyidikan dan sistem koordinasi yang akan dibuat. Peraturan perundang-undangan harus disusun sebagai suatu kesatuan integral dengan keseluruhan kebijakan/proses/sistem penegakan hukum pidana. Kesatuan integral yang dimaksud tidak hanya pada mekanisme/prosesnya, tetapi juga pada spirit/jiwa/idenya yaitu bahwa kekuasaan/kewenangan suatu subsistem merupakan bagian integral dari kebijakan/kekuasaan/kewenangan penegakan hukum yang merupakan kekuasaan yang bebas, mandiri dan merdeka. Adanya kesadaran atas kebijakan penanggulangan kejahatan terpadu (integrated crime policy) yang berdasarkan pada statistik kriminal terpadu (integrated crime statistic) serta profil kejahatan (crime profile) yang dikaitkan dengan perkembangan kejahatan yang terjadi baik secara 
kuantitas maupun kualitas. ${ }^{3}$ Juga disadari adanya saling ketergantungan (interdependensi) antara angka penyelesaian perkara (clearance rate), angka pemidanaan (conviction rate), disparitas pidana, angka pemidanaan kembali (reconviction rate) serta proses penegakan hukum (law making process) dan kepatuhan/kesadaran hukum (law awareness). ${ }^{4}$ Menurut Taverne bukan rumusan undang-undangnya yang menjamin kebaikan pelaksanaan hukum acara pidana, tetapi hukum acara pidana yang jelek dapat menjadi baik, apabila pelaksanaannya ditangani oleh aparat penegak hukum yang baik. ${ }^{5}$

Keterpaduan sistem peradilan pidana harus diarahkan pada penanggulangan kejahatan yang berlandaskan precise justice .yang mengandung unsur precise, and minute fact finding justice, managed by a group of well trained and hard working professionals meskipun sulit di dalam pengimplementasiannya terutama karena sistem peradilan pidana merupakan sistem yang terbuka. ${ }^{6}$

Pada dasarnya hukum itu mempunyai kekuatan memaksa yang dapat diterima oleh masyarakat luas yang bersumber pada pranatanya dan penegakan hukumnya. Oleh sebab itu, dimensi moral harus dimasukkan ke dalam dua hal tersebut di atas agar dapat menjamin terlaksananya penegakan hukum secara baik dan guna memberi perlindungan pada masyarakat luas. Yang kesemuanya itu beroperasi melalui aparat penegak hukum yang berada dalam wadah suatu lembaga/organisasi. Menurut Muladi, sikap fragmentaris dalam penegakan hukum tidak akan terjadi, apabila aparat penegak hukum dilandasi visi dan misi yang sama bahwa sistem peradilan pidana pada dasarnya mempunyai tujuan akhir yakni mencapai kesejahteraan masyarakat (social welfare) dan perlindungan sosial (social protection). Masing-masing struktur penegak hukum sebenarnya hanya merupakan subsistem dari sistem yang besar, yang kesendiriannya tidak akan bermakna apa-apa. Dalam hal demikian, pendidikan para penegak hukum yang relatif terintegrasi dapat memecahkan sebagian kendala. ${ }^{7}$

\section{B. Kendala Yang Ditemui Dalam Upaya Ditresnarkoba Polda Sumbar Dalam Mewujudkan Sistem Peradilan Pidana Terpadu Pada Tahap Penyidikan Tindak Pidana Narkotika}

Polri sebagai bagian dari Sistem Peradilan Pidana Indonesia mempunyai peran yang sangat penting dalam penegakan hukum pidana. Dalam Kitab Undang-Undang Hukum Acara Pidana disebutkan bahwa Polri adalah Penyelidik dan Penyidik.

Sistem Peradilan Pidana pertama-tama ditandai oleh adanya penerapan pendekatan administrasi di sepanjang proses peradilan pidana. Sistem Peradilan Pidana selanjutnya dilihat sebagai suatu hasil interaksi antara peraturan perundang-undangan, praktek administrasi dan sikap atau tingkah laku sosial. Pengertian sistem ini mengandung implikasi suatu proses interaksi, yang dipersiapkan secara rasional dan

\footnotetext{
3 Muladi, Makalah disampaikan pada "Seminar Kewenangan Penyidikan dalam Sistem Peradilan Pidana di Indonesia”, Program Doktor Ilmu Hukum Universitas Diponegoro, Semarang, 2002, hlm3

${ }^{4}$ Edi Setiadi, sistem Peradilan Pidana Terpadu dan system Penegakan Hukum pidana Di Indonesia, Gramedia Pustaka Utama, Jakarta, 2017, hlm 46

${ }_{5}^{5}$ Mohammad Hatta, Sistem Peradilan Pidana Terpadu, Galangpress Group, Jakarta, 2008, hlm 87

${ }^{6}$ Ibid., hlm.92-93.

${ }^{7}$ Muladi, Op., Cit, hlm 89
} 
dengan cara efisien, untuk memberikan hasil tertentu dengan segala keterbatasannya. ${ }^{8}$ Penyidik pada Satresnarkoba Polda Sumbar sebagai bagian dari sistem peradilan pidana terpadu mengalami berbagai kendala dalam upaya mewujudkan sistem peradilan pidana terpadu tersebut.

Adapun kendala yang dialami antara lain Sistem/Lembaga Peradilan Pidana Belum Terpadu maksudnya sistem tersebut akan dapat berhasil apabila sebagian laporan dan keluhan masyarakat yang menjadi korban kejahatan dapat ditangani dan diselesaikan, yang pada akhirnya diajukan ke pengadilan untuk mendapatkan putusan yang setimpal. Keberhasilan sistem tersebut sangat tergantung pada kerjasama dan koordinasi semua komponen yang terlibat di dalam sistem tersebut, di dalam apa yang disebut sebagai integrated criminal justice system. ${ }^{9}$ Masih tampaknya gejala fragmentaris pada gerak operasional sub-subsistem peradilan pidana pada satu sisi dan pada sisi lain adanya urgensi pemahaman pendekatan sistem terhadap penegakan hukum pidana sudah merupakan suatu hal yang mendesak terutama pada tahap penyidikan.

Pendekatan sistem terhadap penegakan hukum pidana berkaitan dengan adanya kebutuhan sinkronisasi pembentukan, pelaksanaan dan penegakan hukum di bidang hukum pidana sebagai upaya untuk mewujudkan sistem peradilan pidana yang terpadu (integrated criminal justice system). Pada dasarnya sistem peradilan pidana merupakan subsistem penegakan hukum dan lebih luas lagi merupakan subsistem sosial, oleh sebab itu kultur penegakan hukum serta segi kemasyarakatan harus diperhatikan.

Kendala lain adalah Lembaga penyidikan belum mandiri. Sistem/Lembaga peradilan pidana belum berwibawa karena undang undang masih memberikan peluang kepada lembaga lain selain Kepolisian dalam melakukan penyidikan suatu tindak pidana. Hal ini berakibat terjadinya tumpeng tindah kewenangan dalam melakukan penyidikan. sistem koordinasi yang akan dilakukan dengan penuntut umum pun menjadi terpengaruh diakibatkan system ini. Penyatuan pemahaman terhadap hasil penyidikan merupakan suatu hal yang menentukan hasil penyidikan.

Dilihat dari aspek substansi hukum sebagaimana dijelaskan dalam teori Lawrence M. Friedman mengenai substansi hukum, terlihat bahwa kenyataan adanya instansi penyidik di luar kepolisian menunjukan tidak adanya sinkronisasi dengan desain yang ditata dalam KUHAP Tahun 1981 sebagai induk hukum acara pidana. Sebagaimana diketahui bahwa dalam subsistem penyidikan terdapat beberapa instansi yang melaksanakan penyidikan. Selain POLRI juga terdapat PPNS (Pajak, Bea Cukai, Pasar Modal, Kehutanan, Lingkungan Hidup, Haki) serta Penyidik dalam tindak pidana khusus (Kejaksaan, KPK, BNN, Perwira TNI AL). Dengan begitu banyaknya instansi yang menangani penyidikan, maka tidak mustahil bahwa akan banyak terjadi tumpang tindih dan pertentangan dalam pelaksanaannya.

Sedangkan dari sudut kelembagaan, hal tersebut kurang menggambarkan adanya sebuah struktur yang mandiri dan terpadu dalam melakukan penyidikan karena terdapat beragam institusi yang masing-masing memiliki struktur organisasi sendiri dan sudah pasti

8 Anton F. Susanto, Wajah Peradilan Kita, konstruksi Sosial Tentang Penyimpangan, Mekanisme kontrol dan Akuntabilitas Peradilan Pidana, Refika Aditama, Bandung, 2004, hlm. 74.

${ }^{9}$ Bambang Dwi Baskoro, Bunga Rampai Penegakan Hukum Pidana, Rajawali Pres, Jakarta, 2001, hlm.188. 
juga memiliki tujuan sendiri-sendiri karena faktor tekanan organisasi itu sendiri dan lain sebagainya. Dampak lebih jauh dari keadaan yang demikian itu adalah munculnya sifat instansi centris, dan hal ini sangat tidak menguntungkan jika dilihat dari sudut usaha membangun kultur masyarakat untuk sadar hukum yang bisa berperan aktif dalam proses penegakan hukum pidana. Kerugian lain adalah bahwa data kriminal tidak dapat terpusat dan terpencar serta sulit dievaluasi untuk mengetahui keberhasilan dan kegagalan masingmasing subsistem peradilan pidana dan sebagainya.

\section{KESIMPULAN}

Upaya Ditresnarkoba Polda Sumbar Dalam Mewujudkan Sistem Peradilan Pidana Terpadu Pada Tahap Penyidikan Tindak Pidana Narkotika adalah dengan mengadakan koordinasi dengan BNN dalam hal rekomendasi rehabilitasi. Pada perkara yang apabila tersangkanya adalah anak anak juga dilakukan keterpaduan sistem dengan lembaga Bapas pada Kanwil Hukum dan HAM di Kota Padang. Setelah penyidikan dianggap selesai Penyidik menyerahkan berkas perkara kepada penuntut umum dan dilakukan tahap pra penuntutan. Penyidik ketika sudah memulai melakukan penyidikan/pemeriksaan, memberitahukan hal itu kepada penuntut umum/kejaksaan. Hubungan dengan Pengadilan Negeri dengan keputusannya memberikan izin terhadap upaya paksa yang dilakukan penyidik. Kendala Yang Ditemui Dalam Upaya Ditresnarkoba Polda Sumbar Dalam Mewujudkan Sistem Peradilan Pidana Terpadu Pada Tahap Penyidikan Tindak Pidana Narkotika adalah Sistem/Lembaga Peradilan Pidana Belum Terpadu. Masih tampaknya gejala fragmentaris pada gerak operasional sub sistem peradilan pidana terutama pada tahap penyidikan.

\section{DAFTAR PUSTAKA}

Puri Rahardi, Hukum Kepolisian (Profesionalisme dan Reformasi Polri), Laksbang Mediatama, Surabaya, 2007.

Barda Nawawi Arief, Bunga Rampai Hukum Pidana, Penerbit Alumni, Bandung, 1992.

Muladi, Makalah disampaikan pada "Seminar Kewenangan Penyidikan dalam Sistem Peradilan Pidana di Indonesia", Program Doktor Ilmu Hukum Universitas Diponegoro, Semarang, 2002.

Edi Setiadi, sistem Peradilan Pidana Terpadu dan system Penegakan Hukum pidana Di Indonesia, Gramedia Pustaka Utama, Jakarta, 2017.

Mohammad Hatta, Sistem Peradilan Pidana Terpadu, Galangpress Group , Jakarta, 2008.

Anton F. Susanto, Wajah Peradilan Kita, konstruksi Sosial Tentang Penyimpangan, Mekanisme kontrol dan Akuntabilitas Peradilan Pidana,Refika Aditama, Bandung, 2004.

Bambang Dwi Baskoro, Bunga Rampai Penegakan Hukum Pidana, Rajawali Pres, Jakarta, 2001. 